Buca Eğitim Fakültesi Dergisi, 2021, Say1 51, s.520-535

Araştırma Makalesi
The Journal of Buca Faculty of Education, 2021, Issue 51, p.520-535

Original Research

\title{
Sosyal Medya Kullanım Bozukluğu Ölçeği: Türkçe Uyarlama Çalışması
}

\section{Social Media Use Disorder Scale: Turkish Adaptation Study}

\author{
Evren ERZEN ${ }^{1}$, Hatice ODACI
}

\begin{abstract}
${ }^{1}$ Sorumlu yazar, Dr. Öğr. Üyesi, Eğitim Bilimleri Bölümü, Ĕgitim Fakültesi, Artvin Çoruh Üniversitesi,Türkiye,evrenerzen@hotmail.com, (https://orcid.org/0000-0001-9726-2688)

${ }^{2}$ Prof. Dr., Psikoloji Bölümü, Edebiyat Fakültesi, Karadeniz Teknik Üniversitesi, Türkiye, hatodaci@hotmail.com, (https://orcid.org/0000-0002-2080-6269)
\end{abstract}

Geliş Tarihi:08/09/2021

Kabul Tarihi:10/06/2021

\section{ÖZ}

$\mathrm{Bu}$ çalışmanın amacı sosyal medya bağımlılığının belirlenmesinde uraştırmacılara alternatif sunabilecek bir ölçme aracının Türkçeye uyarlamasının yapılmasıdır. Çalışma grubu, yaşları 18 ile 39 arasında değişen 453 katılımcıdan $\left[231_{(51 \%)} \mathrm{klz}, 222_{(49 \%)}\right.$ erkek, Ortyaş $\left.=20.78, \mathrm{Ss}=2.20\right]$ oluşmaktadır. Ölçeğin uyarlamasında çeviri geçerliği için Lawshe içerik geçerliği katsayısından, Türkçe dil ve anlam geçerliği hesaplamaları için Cohen Kappa uyuşma indeksinden yararlanılmıştır. Yapı geçerliğinin belirlenmesi için gerçekleştirilen faktör analizlerinin ardından ölçekteki 13 maddenin üç faktör altında tutarlı şekilde toplandıkları gözlenmiştir. Doğrulayıcı faktör analizinden elde edilen uyum değerleri $\chi^{2} / \mathrm{sd}=2.35$, RMSEA $=0.5, \mathrm{GFI}=.95$, CFI ve AGFI ise .93 olarak belirlenmiştir. Ölçeğin güvenirlik analizi sonucunda zorlanma, kaçış ve ssrar alt boyutları ile ölçeğin bütünü için elde edilen Cronbach Alpha iç tutarlılık katsayıları .72, $71, .71$ ve .76 'dır. Yapı güvenirliği katsayıları ise. $78, .79, .82$ ve .91 olarak tespit edilmiştir.

Anahtar Kelimeler: Sosyal medya bağımlılı̆̆ı, sosyal medya kullanım bozukluğu, ölçek, uyarlama, geçerlik ve güvenirlik.

\begin{abstract}
The purpose of this study is to adapt a measurement tool to Turkish that can offer an alternative to researchers in determining social media addiction. Study group is consisted of 453 participants [231 ${ }_{(51 \%)}$ female, $222_{(49 \%)}$ male, $\left.M_{\text {age }}=20.78, \mathrm{Sd}=2.20\right]$. In the adaptation of the scale, Lawshe content validity coefficient was used for translation validity and Cohen Kappa agreement measurement was used for Turkish language and meaning validity calculations. After factor analysis to determine the construct validity, it was observed that 13 items in the scale were consistently collected under three factors. Compliance values obtained from confirmatory factor analysis were determined as $\chi^{2} / \mathrm{df}=2.35$, RMSEA $=$ 0.5 , GFI $=.95, \mathrm{CFI}$ and AGFI .93.As a result of the reliability analysis of the scale, Cronbach Alpha internal consistency coefficients obtained for operation, escape and persistance sub-dimensions and the whole scale were $.72, .71, .71$ and .76 . The composite reliability coefficients were $.78, .79, .82$ and .91 .
\end{abstract}

Keywords: Social media addiction, social media disorder, scale, adaptation, validity and reliability. 


\section{GİRIŞ}

İnternet, bilgisayar, tablet ve akıllı telefonlar günlük yaşamın vazgeçilmez bir parçası haline gelmiştir. Günümüzde yalnız kişisel değil kamusal alandaki birçok iş de artık internet üzerinden gerçekleştirilmektedir. E-okul, e-devlet, e-fatura, internet bankacıllğ gibi birçok uygulama interneti bir bilgi kaynağı, oyun ve eğlence aracı olmaktan çıkartıp gündelik yaşamın zorunlu bir parçasına dönüştürmektedir. Bu sebeple tüm dünyada internet kullanıcılarının oranı 2018 ile 2019 yılları arasında \%9 artışla 4 milyar 390 milyona ulaşmıştır (Kemp, 2019). İnternetin kullanım yaygınlığı arttıkça şüphesiz günlük işler daha da hızlanmakta ve kolaylaşmaktadır. Fakat internetin oyun ve eğlence olanaklarını da kolaylaştırması insanları bu alanlara bağımlı hale getirebilmektedir. İnternet ve kullanım alışkanlıkları üzerine düzenli istatistiki araştırmalar yürüten We are social platformunun 2018 y1lı istatistiklerine göre dünya nüfusunun \%42'si bir sosyal ağa bağlı durumda. Ayrıca insanların \%71'i telefonlarıyla birlikte veya telefonlarını yakın mesafeye koyarak uyumakta ve bu yüzden uyku problemleri yaşamaktadır. Nihayetinde dünya çapında 210 milyon kişinin sosyal medya bağımlılığından şikâyetçi olduğu bilinmektedir (Erdensoy, 2018). Benzer çalışmalar sosyal medyanın Türkiye'de de artan oranlarda bağımlılığa dönüşmekte olduğuna işaret etmektedir (Güneş ve diğ., 2018; Kırık ve diğ., 2015). Bu açıdan bakıldığında her ne kadar sunduğu kolaylıklarla yaşamı kolaylaştırsa da, uygun şekilde kullanılmaması sebebiyle sosyal medyanın küresel çapta ciddi bir probleme dönüşmeye başladığını söylemek mümkündür.

Sosyal medya; bireylerin bilgi, düşünce ve kişisel mesajlarını bir web sitesi veya uygulama kullanarak çevrimiçi bir toplulukla paylaşmaya olanak veren elektronik bir iletişim anlamına gelmektedir (Merriam-Webster, 2019). Bu haberleşme ağ 1 son 30 yıl içerisinde yoğun bir biçimde hayatımıza girmiş ve bireyler arasındaki etkileşimi önemli ölçüde kolaylaştırmıştır. Elektronik posta gönderimi, elektronik sohbet odaları (chat) gibi uygulamalarla ortaya çıkan sosyal medya; Facebook, Twitter, Youtube ve İnstagram gibi uygulamalar aracılığıyla giderek kişilerin özel yaşamlarına ait detaylı ve güncel bilgi paylaşmalarına olanak veren bir yapıya dönüşmüştür (Hendricks, 2013; Terrell, 2019). Fakat bu iletişim ve paylaşım ağının aşırıya kaçan kullanımları gündelik yaşamın işleyişine olumsuz etki etmeye başlamış ve bir bağımlılığa sebep olmuştur.

Bireyin bir saatten daha uzun bir süre sosyal medyadan uzak kalmakta yetersizlik göstermesi olarak tanımlanan sosyal medya bağımlılığ (Hope 2018'den aktaran Thomas, 2018), sosyal medyanın önemli kanallarından Facebook (Atroszko vd., 2018; Griffiths, 2012), Twitter (Chang, 2011; Kircaburun, 2016), İnstagram (Kircaburun ve Griffiths, 2018), Youtube (Balakrishnan ve Griffiths, 2017; Moghavvemi vd., 2017), Whatsapp (Singh, 2014) gibi uygulamalar aracılığı ile bireyleri bağımlılığa sürükleyen bir kaynak haline gelmiştir. Bunun bir sonucu olarak ruh sağlığı uzmanları da ilgilerini bu alana yöneltmiş ve çalışmalarını bu alanda yoğunlaştırmışlardır. Elbette bu araştırmalarda analiz edilebilecek verilerin toplanması sürecinde ölçme araçlarına ihtiyaç duyulmuştur. Nitelikleri ölçülmek istenen olguların kavramsallaştırma ve yapısal özelliklerinin ortaya çıkarılmasında, ölçeklerin kullanımı işlevsel hale gelmektedir (Neuman, 2011). Bu durum sosyal medya bağımlılığını ölçmeyi amaçlayan ölçme araçlarının geliştirilmesini gerekli kılmıştır.

Literatürde sosyal medya bağımlılığını ölçme amacını taşıyan bazı ölçekler bulunmaktadır (A ğyar ve Uzun, 2018; Andreassen vd., 2016; Karadağ vd., 2015). Sosyal medya bağımlılı̆̆ her bir ölçekte farklı sorularla, farklı faktörler altında ölçülmektedir. Bu durum araştırmacılara amaçlarına uygun özellikte olan ölçeği seçme olanağı sunmaktadır. Her bir ölçme aracının soru sayısı, uygulanma süresi, Likert skalasındaki derece sayısı değişebilmektedir. Araştırmacılar amaçlarına uygun olan ölçeği tercih edebilmekte ve çalışmalarının içeriğine uygun ölçümler gerçekleştirebilmektedir. Dolayısıyla aynı kavramı ölçen çok sayıda ölçme aracının varlığı önemli bir avantaj sağlamaktadır. Bu sebeple bu çalışma kapsamında Van Den Eijnden ve diğerleri (2016) tarafından geliştirilmiş olan Sosyal Medya Kullanım Bozukluğu Ölçeği'nin (Social Media Disorder Scale) Türkçeye uyarlanmasının araştırmacılara katkı sağlayacağ1 
düşünülmektedir. Uyarlaması gerçekleştirilecek bu ölçekle birlikte, hem az madde sayısına sahip kullanışlı, hem de yabancı kültürde yer alan fakat Türk kültüründe farklı anlamlara gelebilecek kavramlardan arındırılmış, anlaşılırlığı yüksek, geçerli ve güvenilir bir ölçme aracının geliştirilmesi amaçlanmaktadır. Ayrıca, ölçeğin maddelerine bakıldığında çoklu cevaplama skalasına sahip Likert tipi ölçeklerden farklı olarak "Evet" ve "Hayır" şeklinde iki kesin cevabın verilebileceği görülmektedir. Bu durum, ölçülecek duyguların istatistiki hassasiyet düzeyini azaltmakla birlikte kararsız ve kayıtsız katılımcıların sosyal kabul ile sonuçları manipüle etmeye yönelik hatalı cevaplarının miktarını azaltma potansiyeline sahiptir. Bu açıdan bireyler kendilerinde var olan durumla ilgili orta yol cevap veremeyeceklerinden, yaniltma hatasinın azaltılmasına katkı sağlaması açısından avantajı bir ölçek ortaya çıkartılacağı düşünülmektedir.

\section{YÖNTEM}

\section{1. Örneklem}

Ön uygulama amacıyla seçilen örneklem grubu, yaşları 18 ile 39 arasında değişmekte olan ve öğrenimlerine devam eden 231'i k1z (\%51) ve 222'si erkek (\%49) olmak üzere 453 üniversite öğrencisinden oluşmaktadır (Ort: 20.78, Ss: 2.20). Veriler Doğu Karadeniz Bölgesi'ndeki bir üniversitenin eğitim fakültesindeki öğrencilerden kolay ulaşılabilir örnekleme yoluyla toplanmıştır.

\subsection{Veri Toplama Araçları}

(i) Çalışma kapsamında oluşturulan Kişisel Bilgi Formu (ii) Çeviri Geçerliği Uygunluk Formu (iii) Türkçe Dil ve Anlam Geçerliği Uygunluk Formu (iv) Ölçüt Bağımlı Geçerliğin belirlenmesi için Karadağ ve diğerleri (2015) tarafından geliştirilmiş olan Sosyal Medya Bağımlılığı ve Bergen Sosyal Medya Bağımlılığı Ölçeği (Demirci, 2019) (v) uyarlaması yapılacak olan Sosyal Medya Kullanım Bozukluğu Ölçeği (Van Den Eijnden vd., 2016) veri toplama araçları olarak kullanılmıştır. Ölçekler için ayrılan uygulama süresi 20 dakika ile sınırlı tutulmuştur.

\subsubsection{Sosyal Medya Kullanım Bozukluğu Ölçeği}

Sosyal Medya Kullanım Bozukluğu Ölçeği Van Den Eijnden ve diğerleri (2016) tarafından bireylerdeki hatalı sosyal medya kullanım alışkanlıklarının belirlenmesi amacıyla geliştirilmiştir. Evet ve Hayır yanıtlarından oluşan iki yanıtlı cevaplama skalası bulunan 27 maddeli ölçeğin her biri üçer maddeden oluşan 9 faktörü bulunmaktadır. Bu faktörlerden Meşguliyet faktörü bireyin sosyal medyada geçirdiği aşırı zamanı, Hoşgörü faktörü bireyin giderek artış gösteren sosyal medya kullanımına karşı daha 1lımlı yaklaşıyor olmasını, Vazgeçme faktörü sosyal medya kullanmaktan vazgeçememe düzeyini, Israr faktörü sosyal medya kullanımını azaltma konusundaki başarısız deneyimleri, Yerine geçme faktörü aşırıya kaçan sosyal medya kullanımının gündelik yaşamdaki faaliyetlerin yerine geçmeye başlama düzeyini, Sorunlar faktörü hatalı sosyal medya kullanımının günlük yaşamda sebep olduğu sorunları, Aldanma faktörü sosyal medyayı aşırı bir şekilde kullanabilmek amacıyla başkalarını aldatıcı davranışlar içerisinde girme düzeyini, Kaçış faktörü sorunlu sosyal medya kullanımının günlük yaşamda karşılaşılan olumsuz durumlardan uzaklaşmak için tercih edilme düzeyini , Çatışma faktörü ise sorunlu sosyal medya kullanımı dolayısıyla çevreyle yaşanan çatışmaları ifade etmektedir. Ölçeğin bütünü için Cronbach Alpha güvenirlik katsayısı .90 olarak tespit edilmiştir. Bu çalışmada orijinal ifadesi Social Media Disorder Scale olan ölçeğin Türkçe formu, oluşabilecek anlam karışıklığını engellemek için Sosyal Medya Kullanım Bozukluğu olarak çevrilmiştir. Bu sayede Türk dilinin yapısı dolayısıyla sosyal medyanın değil, sosyal medya kullanımının sorunlu olabileceği belirtilmiştir. 


\subsubsection{Bergen Sosyal Medya Bağımlılığı Ölçeği}

Bergen Sosyal Medya Bağımlılı̆̆ı Ölçeği Andreassen ve diğerleri, (2016) tarafından bireylerdeki sosyal medyaya bağımlılık düzeylerini belirlemek amacıyla geliştirilmiştir. Türkçe uyarlaması ise Demirci (2019) tarafından gerçekleştirilmiştir. 1 (çok nadir) 5 (oldukça sık) şeklinde puanlanan 5 dereceli Likert tipi cevaplama skalasına sahip ölçek tek boyuta ve altı maddeye sahiptir. Ölçeğin Cronbach Alpha güvenirlik katsayısı .88 olarak belirlenmiştir.

\subsubsection{Sosyal Medya Bağımlılığı Ölçeği}

Sosyal Medya Bağımlılığı Ölçeği Karadağ ve diğerleri (2015) tarafından bireylerin sosyal medyaya bağımlılık düzeylerini belirlemek amacıyla geliştirilmiştir. 1 (hiçbir zaman) 5 (her zaman) şeklinde puanlanan 5 dereceli Likert tipi cevaplama skalasına sahip ölçek Paylaşım ve Kontrol adında iki boyuta ve 10 maddeye sahiptir. Ölçeğin Cronbach Alpha güvenirlik katsayıları .82 ve .79 düzeyinde belirlenmiştir.

\section{3. İşlem}

Ölçek uyarlama çalışması kapsamında ilk olarak ölçeğin geliştiricisi Van Den Eijnden ve diğerleri (2016) yazılı izin alınmıştır. Uyarlama çalışması kapsamındaki veri toplama ve analiz süreçlerine ilişkin açıklamalar ise aşağıda aktarılmıştır.

\subsection{1. Çeviri Geçerliği İşlemleri}

Ölçeğin orijinal metinden çevirisinin gerçekleştirilmesi için öncelikle lisansüstü eğitimlerini yurt dışında tamamlamış, ikisi İngiliz Dili ve Edebiyatı bölümünde olmak üzere beş öğretim üyesinin çevrilen maddelerin geçerliğini değerlendirmeleri istenmiştir. Bu doğrultuda uzmanlara Çeviri Geçerliği Derecesi belirten 10 dereceli bir form dağıtılmıştır. Uzmanlardan çeviri işlemi gerçekleştirilen ölçek maddelerinin her biri için 10 dereceli puan cetveline göre puanlama yapmaları istenmiştir. Geçerlilik için 7 puan kesme noktası olarak tespit edilmiştir. Uzmanlar tarafından gerekli görülen incelemeler yapılarak, uygun görülen düzeltmeler formun sonuna açıklama olarak eklenmiş ve çevirisi yapılan maddenin orijinalinin Türkçe'deki anlamını doğru karşılama düzeyine göre puanlama yapılmıştır. Sonuçta gerçekleştirilecek ilk uygulama ve analizlerden önce ölçekte yer alan maddelerin Türkçe karşılıklarının orijinal maddeleri hangi ölçüde karşılayabildiği tespit edilmiştir. Uzmanlar tarafından değerlendirmede kullanılan formun bir örneği Tablo 1'de sunulmuştur.

Tablo 1. Sosyal Medya Kullanım Bozukluğu Ölçeği Çeviri Geçerlik Formu Örneği

\begin{tabular}{|c|c|c|c|c|c|c|c|c|c|c|}
\hline ÖrnekMadde & 1 & 2 & 3 & 4 & 5 & 6 & 7 & 89 & 10 & \\
\hline $\begin{array}{l}\text {...often found it } \\
\text { difficult not to look at } \\
\text { messages on social } \\
\text { media when you were } \\
\text { doing something else } \\
\text { (e.g. schoolwork) }\end{array}$ & & & & & & & & & & $\begin{array}{l}\text {... başka birşey yaparken (örneğin } \\
\text { ödev) sosyal medya mesajlarına } \\
\text { bakmamakta zorlandınız mı? }\end{array}$ \\
\hline
\end{tabular}

\subsection{2. Çeviri Geçerliği İşlemleri}

Türkçe Öğretmenliği bölümünde öğretim üyesi iki uzmandan formdaki tüm maddeleri Türk Dili açısından anlaşılır olma düzeyine göre değerlendirme yapmaları istenmiştir. Çeviri geçerliği için kullanılan formun yalnızca Türkçe maddeleri içeren bir benzeri dil ve anlam geçerliğinin belirlenebilmesi amacıyla hazırlanarak uzmanlara verilmiştir. Uzmanlar tümüyle anlaşılır durumdaki maddelere 10 (on), hiç anlaşılmayan maddelere 1 (bir) aralığında puan vermişlerdir. Ayrıca uzmanlar, düzenleme yapılmasına gerek gördükleri maddeler için görüşlerini ilgili formun altında ayrılan alana yazmışlardır. Ölçek maddelerinin incelenmesinde 
göz önünde bulundurulması istenen kriterler i) ilgili maddenin açık ve basit bir şekilde anlaşılabilmesi, ii) anlatım bozukluğu ve yazım yanlışlarından arınık olması şeklinde belirlenmiştir. Değerlendirme sonucunda tespit edilen kriterlere göre ölçek maddelerinin Türkçe formuna puan verilmiş ve geçerlik düzeyi tespit edilmiştir.

Tablo 2. Sosyal Medya Kullanım Bozukluğu Ölçeği Türkçe Dil ve Anlam Geçerlik Formu Örneği

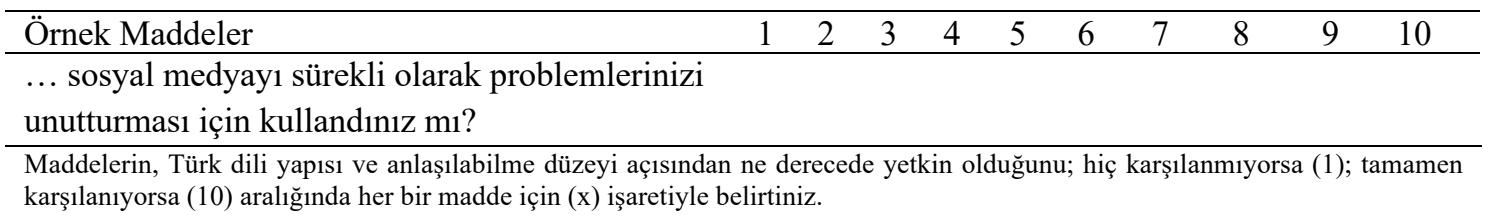

Türkçe dil ve anlam geçerliğinin belirlenebilmesi amaciyla yürütülen analizler sonucunda ölçek maddelerinin Türkçe'de net olarak anlaşılır olup olmadığı uygulamadan önce belirlenmiş ve ölçek ilk uygulama için hazır duruma getirilmiştir. Uzmanlarca değerlendirmede kullanılan Türkçe dil ve anlam geçerliği formuna ilişkin örnek, Tablo 2'de verilmiştir.

\subsubsection{Yapı Geçerliği İşlemleri}

Çeviri geçerliliği işlemlerinin ardından açımlayıcı faktör analizi, madde toplam, madde ayırt edicilik, ve doğrulayıcı faktör analizlerine geçilmiştir.

\subsubsection{Güvenirlik İşlemleri}

Ölçeğin iç güvenilirlik düzeyinin tespit edilmesi amacıyla Cronbach Alpha katsayılarından yararlanılmıştır. Ölç̧eğin yapı güvenilirlik düzeyini belirlemek için yapı güvenirliği (composite reliability) analizi gerçekleştirilmiştir.

\section{BULGULAR}

\section{1. Çeviri Geçerliği Bulguları}

Uyarlanan ölçek maddelerinin orijinal metindeki anlamı yansıtma düzeyi için uzmanlar tarafindan 10 üzerinden verilen puanlarda sınır değer olarak 7 puan kabul edilmiş ve uzman sayısının 5 olması dolayısıyla Lawshe geçerlik katsayısı formülü (Lawshe, 1975) kullanılmıştır (Formül 1).

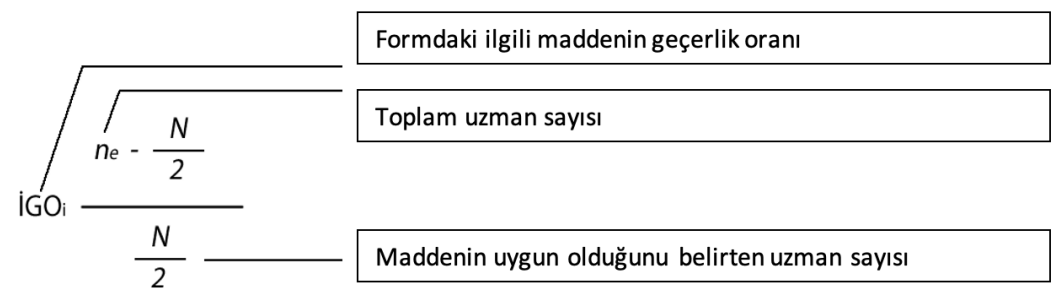

Formül 1. Lawshe İçerik Geçerliği Formülü

Yapılan analizler sonucunda uzmanların fikir birliği sağladığı ve \%100 uyuma işaret eden 1.00 katsayısının elde edildiği görülmektedir. Lawshe içerik geçerliği katsayısının hesaplanmasında uzman sayısının beş olduğu durumda kabul edilebilir geçerlik düzeyi .99'dur. $\mathrm{Bu}$ açıdan sonucun geçerli olduğu görülmektedir.

\subsection{Dil ve Anlam Geçerliği Bulguları}

Ölçek maddelerinin Türk dilinde anlaşılır olma durumunun belirlenebilmesi amacıyla çalışmaya dâhil olan uzman sayısının iki (2) olması dolayısıyla Cohen Kappa uyuşma indeksinden yararlanılmıştır. Değerlendirilmede uzmanlar tarafından 10 üzerinden verilen puanlar için sınır 
değer olarak yedi (7) puan kabul edilmiştir. Çalışma sonucunda Cohen Kappa uyuşma indeksi katsayısının .67 düzeyinde olduğu görülmüştür.

\subsection{Yapı Geçerliği Bulguları}

Uyarlaması yapılan maddelerin yapı geçerliklerinin belirlenmesi amacıyla madde toplam, madde ayırt edicilik ve doğrulayıcı faktör analizi yöntemlerinden faydalanılmıştır. Analizlere ilişkin açıklama ve değerler aşağıda yer almaktadır.

\subsubsection{Açımlayıcı Faktör Analizi}

Sosyal Medya Kullanım Bozukluğu Ölçeğinin geçerlik çalışmaları kapsamında ölçeğin orijinal faktör yapısı doğrulayıcı faktör analizi aracılığ ile test edilmiştir. İlk olarak madde toplam analizinden kalan maddelerle özgün ölçekte belirtilen üçer maddeli model için uyum istatistikleri hesaplanmıştır. Analiz sonuçlarına göre uyum indeksleri $\left(\chi^{2} / \mathrm{df}=2.34, \mathrm{GFI}=0.91, \mathrm{CFI}=0.86\right.$, $\mathrm{TLI}=.83, \mathrm{AGFI}=0.87, \mathrm{RMSEA}=0.05)$, modelin uyumlu olmadığını göstermektedir. Diğer bir ifadeyle ölçeğin orijinal faktör yapısının Türk katılımcılar tarafından doğrulanmadığ görülmektedir. Bu sebeple Türk katılımcıların algıladığı faktör yapısının belirlenebilmesi amacıyla açımlayıcı faktör analizi yapılmış ve Türk katılımcıların orijinal formda yer alan maddeleri hangi faktörler altında daha tutarlı algıladıkları belirlenmiştir. Açımlayıcı faktör analizine başlanmadan önce Kaiser Maier Olkin $(\mathrm{KMO})=.75$ ve Barlett $(\mathrm{p}<.01)$ test sonuçları incelenmiş ve verilerin analize hazır olduğu görülmüsstür. Açımlayıcı faktör analizine orijinal formdaki 27 madde ile başlanmıştır. Varimax dik eksen döndürme tekniği kullanılması tercih edilmiştir. Eksen döndürme teknikleri maddeler arası korelasyon düzeyinin yüksek veya düşük olmasına bağlı olarak belirlenmektedir (Büyüköztürk, 2002). Birbiriyle yüksek korelasyon düzeyine sahip, tek boyutlu olması beklenen maddelerin analizinde ise eğik döndürme metodu tercih edilmektedir (Johnson ve Wichern, 2007; Thompson, 2004). Bu çalışmada ise orijinal formda üçer maddeli her bir alt boyut birbirinden farklı alt temalara işaret edecek şekilde ayrıştırılmış olduğu ve çok boyutlu bir yapıya işaret ettiği için varimax metodu seçilmiştir. Analize dahil edilmeyen maddeler, madde analizleri sırasında anlamlı korelasyon değerlerine sahip olmayan maddelerdir. Analiz sonucunda 27 maddenin 13'e indiği ve üç faktör altında tutarlı şekilde toplandıkları belirlenmiştir. Faktör yüklerinin ise .48 ile .87 arasında dağıldıkları gözlenmiştir (Tablo 3).

Tablo 3. Sosyal Medya Kullanım Bozukluğu Ölçeği Türkçe Formunun Açımlayıcı Faktör Analizi Sonuçları

\begin{tabular}{|c|c|c|c|}
\hline Alt Boyutlar & Zorlanma & Israr & Kaçış \\
\hline Madde 1 & .49 & - & - \\
\hline Madde 3 & .53 & - & - \\
\hline Madde 4 & .76 & - & - \\
\hline Madde 5 & .72 & - & - \\
\hline Madde 6 & .48 & - & - \\
\hline Madde 16 & .57 & - & - \\
\hline Madde 17 & .51 & - & - \\
\hline Madde 10 & - & .87 & - \\
\hline Madde 11 & - & .87 & - \\
\hline Madde 12 & - & .48 & - \\
\hline Madde 13 & - & - & .79 \\
\hline Madde 14 & - & - & .77 \\
\hline Madde 15 & - & - & .80 \\
\hline Öz değer & 26.69 & 13.57 & 10.02 \\
\hline Varyans & 19.89 & 15.70 & 14.69 \\
\hline Toplam var. & $\% 50.30$ & & \\
\hline
\end{tabular}


Sosyal Medya Kullanım Bozukluğu Ölçeği Türkçe formunda, orijinal formda yer alan alt boyutlardan farklı bir faktör yapısının ortaya çıktığı gözlenmiştir. Ortaya çıkan faktör yapısında üç farklı alt boyut altında 13 maddenin yer aldığ 1 tespit edilmiştir. Orijinal faktör yapısında yer alan 10,11, 12. Maddelerden oluşan $\iota s r a r$ ve 13, 14 ve 15. Maddelerden oluşan Kaçı̧s alt boyutunun birebir bu ölçekte de korunduğu buna karşın zorlanma olarak adlandırılan yeni bir faktör yapısının ortaya çıktığı gözlenmiştir. Zorlanma alt boyutuna örnek olarak "Geçen yıl boyunca sosyal medyada yeni bir gelişme olması için sıklıkla oturup beklediniz mi?" maddesi gösterilebilir. Israr alt boyutuna örnek olarak "Geçen yıl boyunca ...sosyal medyada daha az zaman geçirmeyi deneyip başarısız oldunuz mu?" maddesi gösterilebilir. Kaçış alt boyutu içinse "Geçen yıl boyunca hoşunuza gitmeyen şeyleri düşünmemek için sıkça sosyal medya kullandınız mı?" maddesi örnek gösterilebilir. Bu aşamada ortaya çıkan yeni alt boyuta ait maddelerin anlamsal (nomolojik) olarak bir bütünlük sergileyip sergilemedikleri incelenmiş ve kavramsal çerçeve doğrultusunda ilgili maddelerin bir arada bulunmasının mümkün olduğu tespit edilmiştir. Nomolojik ağ incelemesi istatistiki işlemler aracılığıyla belirlenmesi mümkün olmayan fakat söz konusu kavrama ilişkin bulguların alana ait bilgiler doğrultusunda incelenmesi yoluyla elde edilen tespitleri kapsamaktadır (Şencan, 2005). Diğer bir deyişle nomolojik ağ incelemesi istatistiki analizlerle belirlenen sayısal değerlerin anlamsal olarak doğruluk gösterip göstermediğini, alana iliş̧kin bilgiler doğrultusunda incelemek anlamına gelmektedir. Orijinal ölçekte yer alan 1., 3 ., 4., 5., 6., 16. ve 17. maddelerin günlük yaşantıdaki rutin işleyiş̧in bozulmasıyla alakalı olduğu ve bu bağlamda ortak özellikler sergiledikleri görülmektedir. Sonuç olarak üç faktör altında toplanmış olan 13 maddenin, toplam varyansın \%50.30'unu açıkladığı görülmektedir. Açımlayıcı faktör analizinde toplam varyansın \%40 ve üzerinin açıklanmış olmasının kabul edilebilir olduğu (Kline, 1994) göz önüne alındığında elde edilen \%50’lik değerin yeterli olduğu belirlenmiştir.

Analizler sonucunda orijinal ölçekte yer alan, hoşgörü (Tolerance), israr (Persistence) ve kaçış (Escape) alt boyutlarındaki maddelerin tamamen; meşguliyet (Preoccupation) ve sorunlar (Problems) alt boyutlarındaki maddelerin ise kısmen ölçekte yer almayı sürdürdüğü belirlenmiştir. Buna karşın yerine geçme (Displacement), aldanma (Deception), çatışma (Conflict) ve vazgeçme (Withdrawal) alt boyutlarındaki maddelerin ise Türk katılımcılar açısından anlamlı bulunmadığı tespit edilmiştir. Oluşan üç boyutlu yeni faktör yapısında orijinal ölçekte Meşguliyet, Hoşgörü ve Sorunlar alt boyutları altında yer alan maddelerin bir araya toplandığ 1 görülmektedir. Bu maddeler arasında "Geçen yıl boyunca başka bir şey yaparken (örneğin ödev) sosyal medya mesajlarına bakmamakta zorlandınız mi? [Meşguliyet] Geçen yıl boyunca sıklıkla gece geç saatlere kadar sosyal medya kullandiğınız için uykusuz kaldınız mı? [Sorunlar] Geçen yıl boyunca sosyal medyayı daha sık kullanmak istediğiniz için mutsuzluk hissettiniz mi? [Hoşgörü]" gibi maddelerin olduğu gözlenmektedir. Orijinal ölçekte farklı boyutlar altında yer alan ve Türk katılımcılar tarafindan benzer nitelikte olarak bir arada algılanan bu maddelere bakıldığında, bireyin sosyal medya kullanımından uzak kalabilme konusunda yaşadığı zorlanma hissine atıfta bulunulduğu belirlenmiştir. Bu sebeple araştırmacılar tarafindan meydana gelen bu yeni faktöre Zorlanma adı verilmesi uygun görülmüştür. Orijinal ölçekte yer alan Kaçıs ve Israr faktörleri ise tüm maddeleriyle birlikte korunduğu için bu faktörlerde bir isim değişikliği yapılmamıştır.

Ölçeğin alt boyutları arasındaki ilişkinin tespit edilebilmesi amacıyla Pearson Momentler Çarpımı Korelasyon analizi gerçekleştirilmiştir. Kaçış alt boyutu için ortalama puan 1,26 ( $\mathrm{S}=1.17)$, Israr için .94 ( $\mathrm{SS}=1.09)$ ve zorlanma için 2.87 ( $\mathrm{SS}=2.07$ )'dir. Ölçekte yer alan tüm alt boyutların birbirleriyle anlamlı düzeyde ilişkili oldukları Pearson Momentler Çarpımı Korelasyonu aracılı̆g 1 ile tespit edilmiştir. Bu bağlamda kaçış ile 1 srar $(r=.12, p<.01)$, kaçış ile zorlanma $(r=.20, p<.01)$ ve 1 srar ile zorlanma pozitif yönde anlamlı ilişkiye sahiptir $(r=.58$, $p<.01)$.

\subsubsection{Madde Analizi Bulguları}

Sosyal Medya Kullanım Bozukluğu Ölçeğinin Türkçe formunun yap1 geçerliğinin belirlenmesine yönelik analizlerin gerçekleştirilmesinden önce, eldeki verilerin analiz için uygun 
olup olmadığı test edilmiştir. Öncelikle veri setindeki toplam puanlara $Z$ testi yapılmıştır. $Z$ testi sonucunda eldeki verilerin -3 ile +3 aralığında bulunduğu belirlenmiştir. Sonrasında Cronbach Alpha analizi gerçekleştirilmiş ve tüm maddelerin madde toplam korelasyonu değerlerinin anlamlı olduğu belirlenmiştir. (Tablo 4).

Tablo 4. Ölçek Maddelerine İlişkin Cronbach Alpha Değerleri

\begin{tabular}{lccc}
\hline Madde & $\begin{array}{c}\text { Madde Silinirse } \\
\text { Ortalama }\end{array}$ & $\begin{array}{c}\text { Madde Silinirse } \\
\text { Varyans }\end{array}$ & $\begin{array}{c}\text { Düzeltilmis Madde Toplam } \\
\text { Korelasyonu }\end{array}$ \\
\hline Madde 1 & 4.47 & 8.55 & $.43^{* *}$ \\
Madde 3 & 4.80 & 9.05 & $.34^{* *}$ \\
Madde 4 & 4.61 & 8.56 & $.43^{* *}$ \\
Madde 5 & 4.58 & 8.47 & $.46^{* *}$ \\
Madde 6 & 4.66 & 8.83 & $.35^{* *}$ \\
Madde 10 & 4.65 & 8.57 & $.44^{* *}$ \\
Madde 11 & 4.64 & 8.54 & $.45^{* *}$ \\
Madde 12 & 4.79 & 9.02 & $.35^{* *}$ \\
Madde 13 & 4.66 & 9.03 & $.27^{* *}$ \\
Madde 14 & 4.55 & 9.02 & $.26^{* *}$ \\
Madde 15 & 4.55 & 8.82 & $.33^{* *}$ \\
Madde 16 & 4.57 & 8.49 & $.45^{* *}$ \\
Madde 17 & 4.55 & 8.62 & $.40^{* *}$ \\
\hline$*$ * p
\end{tabular}

\subsubsection{Madde Ayırt Edicilik Bulguları}

Ölçek maddelerine ait ayırt edicilik gücünün belirlenebilmesi için her bir alt boyut bağlamında elde edilen ham puanlar yüksekten düşüğe doğru sıralanmıştır. Sıralama neticesinde belirlenen alt $\% 27$ ve üst \%27'lik dilimi teşkil eden grupların puan ortalamalarının karşılaştırılması için bağımsız gruplar $t$ testinden yararlanılmıştır.

Tablo 5. Sosyal Medya Kullanım Bozukluğu Ölçeğinin Ayırt Edicilik Güçlerinin Belirlenmesi Amacıyla Yapılan Bağımsız Gruplar t testi Sonuçları

\begin{tabular}{|c|c|c|c|c|c|c|c|c|c|c|c|}
\hline Madde & & $\mathrm{X}$ & $\mathrm{S}$ & $\mathrm{t}$ & $\mathrm{p}$ & Madde & & $\mathrm{X}$ & $\mathrm{S}$ & $\mathrm{t}$ & $\mathrm{p}$ \\
\hline Madde 1 & $\begin{array}{l}\text { Alt } \% 27 \\
\text { Üst } \% 27\end{array}$ & $\begin{array}{l}.00 \\
1.00\end{array}$ & $\begin{array}{l}.00 \\
.00\end{array}$ & $\S$ & .00 & Madde 13 & $\begin{array}{l}\text { Alt } \% 27 \\
\text { Üst } \% 27\end{array}$ & $\begin{array}{l}.00 \\
1.00\end{array}$ & $\begin{array}{l}.00 \\
.00\end{array}$ & $\S$ & .00 \\
\hline Madde 2 & $\begin{array}{l}\text { Alt } \% 27 \\
\text { Üst } \% 27\end{array}$ & $\begin{array}{l}.00 \\
.57\end{array}$ & $\begin{array}{l}.00 \\
.49\end{array}$ & -12.89 & .00 & Madde 14 & $\begin{array}{l}\text { Alt } \% 27 \\
\text { Üst } \% 27\end{array}$ & $\begin{array}{l}.00 \\
1.00\end{array}$ & $\begin{array}{l}.00 \\
.00\end{array}$ & $\S$ & .00 \\
\hline Madde 3 & $\begin{array}{l}\text { Alt } \% 27 \\
\text { Üst } \% 27\end{array}$ & $\begin{array}{l}.00 \\
1.00\end{array}$ & $\begin{array}{l}.00 \\
.42\end{array}$ & -20.15 & .00 & Madde 15 & $\begin{array}{l}\text { Alto } \% 27 \\
\text { Üst } \% 27\end{array}$ & $\begin{array}{l}.00 \\
1.00\end{array}$ & $\begin{array}{l}.00 \\
.00\end{array}$ & $\S$ & .00 \\
\hline Madde 4 & $\begin{array}{l}\text { Alt } \% 27 \\
\text { Üst } \% 27\end{array}$ & $\begin{array}{l}.00 \\
.77\end{array}$ & $\begin{array}{l}.00 \\
.00\end{array}$ & $\S$ & .00 & Madde 16 & $\begin{array}{l}\text { Alt } \% 27 \\
\text { Üst } \% 27\end{array}$ & $\begin{array}{l}.00 \\
1.00\end{array}$ & $\begin{array}{l}.00 \\
.00\end{array}$ & $\S$ & .00 \\
\hline Madde 5 & $\begin{array}{l}\text { Alto } \% 27 \\
\text { Üst } \% 27\end{array}$ & $\begin{array}{l}.00 \\
1.00\end{array}$ & $\begin{array}{l}.00 \\
.00\end{array}$ & $\S$ & .00 & Madde 17 & $\begin{array}{l}\text { Alto } \% 27 \\
\text { Üst } \% 27\end{array}$ & $\begin{array}{l}.00 \\
1.00\end{array}$ & $\begin{array}{l}.00 \\
.00\end{array}$ & $\S$ & .00 \\
\hline Madde 6 & $\begin{array}{l}\text { Alt } \% 27 \\
\text { Üst } \% 27\end{array}$ & $\begin{array}{l}.00 \\
1.00\end{array}$ & $\begin{array}{l}.00 \\
.00\end{array}$ & $\S$ & .00 & Madde 18 & $\begin{array}{l}\text { Alt } \% 27 \\
\text { Üst } \% 27\end{array}$ & $\begin{array}{l}.00 \\
.32\end{array}$ & $\begin{array}{l}.00 \\
.47\end{array}$ & -7.71 & .00 \\
\hline Madde 7 & $\begin{array}{l}\text { Alt } \% 27 \\
\text { Üst } \% 27\end{array}$ & $\begin{array}{l}.00 \\
.85\end{array}$ & $\begin{array}{l}.00 \\
.35\end{array}$ & -26.83 & .00 & Madde 19 & $\begin{array}{l}\text { Alt } \% 27 \\
\text { Üst } \% 27\end{array}$ & $\begin{array}{l}.00 \\
.00\end{array}$ & $\begin{array}{l}.00 \\
.00\end{array}$ & $\S$ & .00 \\
\hline Madde 8 & $\begin{array}{l}\text { Alt } \% 27 \\
\text { Üst } \% 27\end{array}$ & $\begin{array}{l}.00 \\
.15\end{array}$ & $\begin{array}{l}.00 \\
.36\end{array}$ & -4.74 & .00 & Madde 22 & $\begin{array}{l}\text { Alt } \% 27 \\
\text { Üst } \% 27\end{array}$ & $\begin{array}{l}.00 \\
1.00\end{array}$ & $\begin{array}{l}.00 \\
.00\end{array}$ & $\S$ & .00 \\
\hline Madde 9 & $\begin{array}{l}\text { Alt } \% 27 \\
\text { Üst } \% 27\end{array}$ & $\begin{array}{l}.00 \\
.55\end{array}$ & $\begin{array}{l}.00 \\
.49\end{array}$ & -12.27 & .00 & Madde 23 & $\begin{array}{l}\text { Alt } \% 27 \\
\text { Üst } \% 27\end{array}$ & $\begin{array}{l}.00 \\
.94\end{array}$ & $\begin{array}{l}.00 \\
.22\end{array}$ & -46.30 & .00 \\
\hline Madde 10 & $\begin{array}{l}\text { Alt } \% 27 \\
\text { Üst } \% 27\end{array}$ & $\begin{array}{l}.00 \\
1.00\end{array}$ & $\begin{array}{l}.00 \\
.00\end{array}$ & $\S$ & .00 & Madde 24 & $\begin{array}{l}\text { Alt } \% 27 \\
\text { Üst } \% 27\end{array}$ & $\begin{array}{l}.00 \\
.98\end{array}$ & $\begin{array}{l}.00 \\
.12\end{array}$ & -85.20 & .00 \\
\hline Madde 11 & Alt $\% 27$ & .00 & .00 & $\S$ & .00 & Madde 25 & Alt $\% 27$ & .00 & .00 & -6.86 & .00 \\
\hline
\end{tabular}




\begin{tabular}{|c|c|c|c|c|c|c|c|c|c|c|c|}
\hline \multicolumn{2}{|l|}{$x_{1}$} & \multirow[b]{2}{*}{1.00} & \multirow[b]{2}{*}{.00} & \multirow{2}{*}{\multicolumn{4}{|c|}{ Üst $\% 27$}} & \multirow[b]{2}{*}{.27} & \multirow[b]{2}{*}{.44} & & \\
\hline 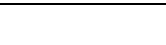 & Üst\%27 & & & & & & & & & & \\
\hline & Alto $\% 27$ & .00 & .00 & & & & Alt $\% 27$ & .00 & .00 & & \\
\hline Madde 12 & Üst\%27 & .79 & .40 & -21.90 & .00 & Madde 26 & Üst $\% 27$ & .16 & .37 & -4.87 & .00 \\
\hline
\end{tabular}

$\mathrm{n}=122+122=244, \mathrm{SD}=121, \S=$ Alt grup tamamen 0 , üst grup da tamamen 1'lerden oluştuğu için standart sapma 0 çıkmakta ve bu sebeple $t$ değeri hesaplanamamaktadır. Fakat alt grup ile üst grupta yer alan cevapların $\% 100$ ayrışmasına işaret eden bu durum en yüksek düzeyde ayırt edicilik bulunduğunu göstermektedir.

Bağımsız gruplar $t$ testi neticesinde, üst ve alt yüzdelik dilimde yer alan grup ortalamaları arasında $\mathrm{p}<.01$ düzeyinde anlamlı bir farklılık olduğu tespit edilmiştir. Ölçek maddelerinin sıfır (0) ve bir (1) değerlerine bağlı olarak ölçüm yapması ve alt grupta yer alan tüm ölçümlerin sıfır üst grupta yer alan tüm ölçümlerin bir olması durumunda ise ölçümlerin standart sapması sıfira eşit olduğundan $t$ değerleri hesaplanamamaktadır. Ancak alt ve üst grup arasındaki tüm puanların farklılaşması dolayısıyla bu maddelerin \%100 ayırt ediciliğe sahip olduğu görülmektedir. Bu açıdan bakıldığında uyarlanan ölçeğin her bir maddesinden elde edilen yüksek puanların ölçeğin amaçladığı özelliği ölçmeye katkı sağladığı söylenebilir. Ölçekte yer alan maddelerin ayırt edicilik gücü değerlerini belirlemek amacıyla yapılan bağımsız gruplar $t$ testi sonuçları Tablo 5 'te sunulmuştur.

\subsubsection{Doğrulayıcı Faktör Analizi}

Açımlayıcı faktör analizi sonucunda ölçek maddelerinin hangi faktörler altında bütünlük gösterdiği belirlendikten sonra doğrulayıcı faktör analizine geçilmiş ve belirlenen yapının geçerliği sınanmıştır. Oluşan formun doğrulayıcı faktör analizi sonuçlarına göre oluşan yapının uyumlu olduğu belirlenmiştir. Elde edilen uyum indekslerine ilişkin sonuçlar Tablo 6'da özetlenmiştir. Ayrıca maddelerin faktör yükleri ve kovaryans değerleri Şekil 1'deki doğrulayıcı faktör analizi şemasında sunulmuştur.

Tablo 6. Sosyal Medya Kullanım Bozukluğu Ölçeğine İlişkin Doğrulayıcı Faktör Analizi Sonuçları

\begin{tabular}{llll}
\hline Uyum İndeksleri & SMBÖ & Sinır Değerler & Kaynak \\
\hline $\mathrm{X}^{2} /$ sd & 2.35 & $\leq 3.00$ Mükemmel uyum & R. Kline (2010) \\
RMSEA & 0.05 & $\leq 0.05$ Mükemmel uyum & Joreskog ve Sorbom (1993) \\
GFI & 0.95 & $\geq 0.90$ Iyi Uyum & Hooper, Coughlan ve Mullen (2008) \\
CFI & 0.93 & $\geq 0.90$ İyi Uyum & Tabachnick ve Fidell (2007) \\
AGFI & 0.93 & $\geq 0.90$ İyi Uyum & Hooper, Coughlan ve Mullen (2008) \\
\hline \multicolumn{2}{l}{ SMBÖ: Sosyal Medya Kullanım Bozukluğu Ölçeği } &
\end{tabular}

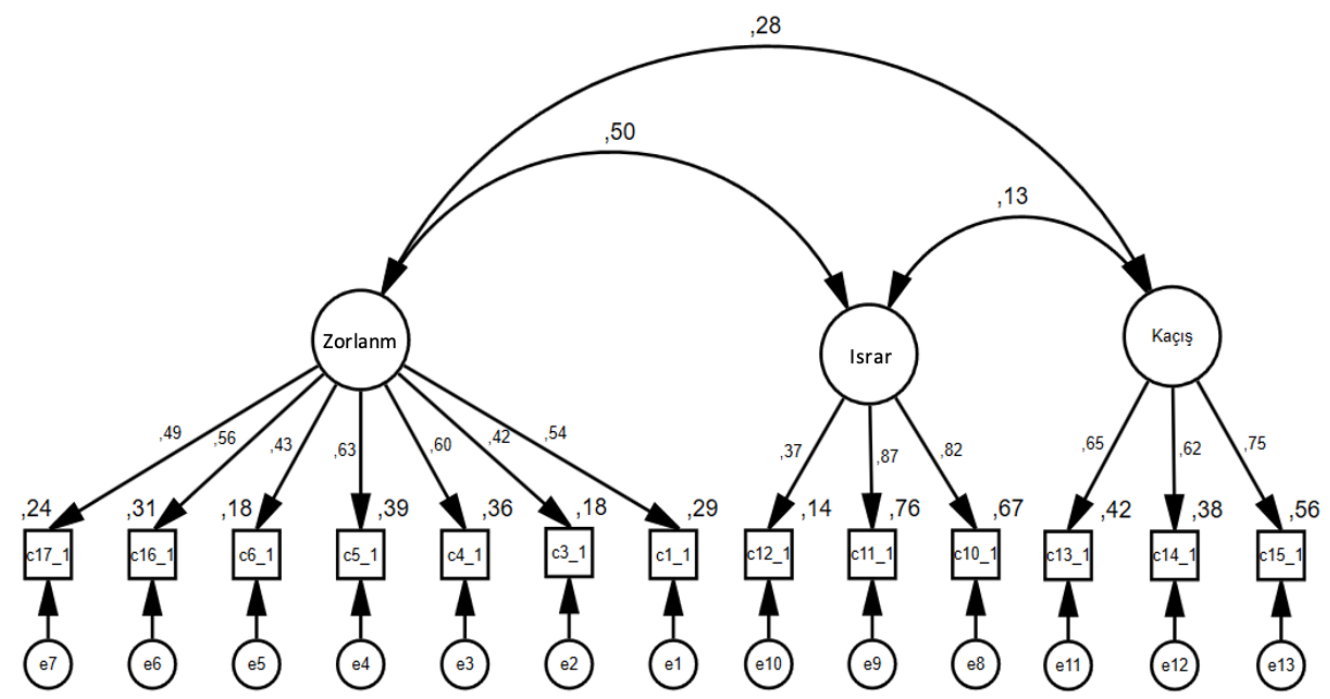

Şekil 1. Sosyal Medya Kullanım Bozukluğu Ölçeği Doğrulayıcı Faktör Analizi Şeması 


\subsection{Kriter Geçerliği Bulguları}

Sosyal Medya Kullanım Bozukluğu Ölçeğinin kriter geçerliğinin belirlenmesi amacıyla ölçekten elde edilen puanların sosyal medya bağımlılı̆̆ıla ilgili kullanılmakta olan benzer nitelikteki ölçeklerden alınan puanlarla korelasyon değerlerine bakılmıştır. Bu bağlamda uyarlaması yapılan Sosyal Medya Kullanım Bozukluğu Ölçeğinin, Bergen Sosyal Medya Bağımlılığı Ölçeği (Demirci, 2019) ve Karadağ ve diğerleri (2015) tarafından geliştirilen Sosyal Medya Bağımlılığı Ölçeği ile anlamlı ilişki içerisinde olduğu belirlenmiştir.

Tablo 7. Sosyal Medya Kullanım Bozukluğu Ölçeği Kriter Geçerliğine İlişkin Korelasyon Analizi Sonuçları

\begin{tabular}{lccc}
\hline & 1 & 2 & 3 \\
\hline Sosyal Medya Kullanım Bozukluğu Ölçeği & 1 & & \\
Bergen Sosyal Medya Bă̆ımlılığı Ölçeği & $.66^{* *}$ & 1 & \\
Sosyal Medya Bağımlılı̆̆ Ölçeği & $.56^{* *}$ & $.64^{* *}$ & 1 \\
\hline$* *$ p $<.001$ & &
\end{tabular}

\subsection{Güvenilirlik Analizi Bulguları}

Ölçeğin güvenilirlik düzeyinin belirlenmesi amacıyla iç tutarlık analizi ve yapı güvenirliği analizleri gerçekleştirilmiştir. Tespit edilen Cronbach Alpha iç tutarlık katsayısı alt boyutlarda İşleyiş için .72, Israr için .71 ve Kaçış için .71 olarak belirlenmiştir. Ölçeğin tamamından elde edilen güvenirlik katsayısı ise .76'dır. Yapı güvenirliği katsayıları ise zorlanma boyutu için .78, 1srar için .79 ve kaçış alt boyutu için .82 olarak tespit edilmiştir. Ölçeğin bütününe ait yap1 güvenirliği katsayısı .91'dir. Yapı geçerliği kapsamında belirlenen Çıkarılmış Ortalama Varyans (Average Variance Extracted, AVE) değerleri ise $.34, .58, .82$ ve .38 'dir.

\section{TARTIŞMA, SONUÇ VE ÖNERILER}

Bu çalışmanın amacı, sosyal medya bağımlılığının ölçümünde kullanılmak için geçerli ve güvenir, araştırmacılara alternatif sunabilecek bir ölçme aracının uyarlanmasıydı. Bu doğrultuda gerçekleştirilen analizler sonucunda 13 maddesi olan 3 faktörlü bir ölçek ortaya çıkmıştır. Orijinal ölçekte de yer alan Israr (Persistence) ve Kaçış (Escape) faktörleri orijinal ölçekte olduğu gibi aynen korunmuş ve 3'er maddeyle Türkçe formda da yer almıştır. Zorlanma faktörü ise Türk katılımcılar tarafından sosyal medya ile meşguliyet, sosyal medya kullanımındaki artışa daha hoşgörü ile yaklaşma ve sosyal medya kullanımının sebep olduğu sorunların bileşkesi olarak aynı faktör altında toplanmıştır. Orijinal ölçekte üç farklı alt boyutta yer alan bu maddelerin ortak noktasına bakıldığında, bireyin sosyal medyayı problemli bir şekilde kullanırken, kendisini bu alışkanlıktan kurtarmak isteyişi fakat kurtaramayışının yarattığı zorlanma duygusunun baskın olduğu görülmektedir. Bu sebeple oluşan bu yeni faktör zorlanma olarak adlandırılmıştır. Orijinal ölçekte de yer alan Israr ve Kaçış faktörleri Türk kültüründe de aynı karşılığı bulmuş ve katılımcılar tarafından anlamlı görülerek oluşan Türkçe formda da varlığını korumuştur. Buna karşın Yerine geçme, Aldanma, Çatışma ve Vazgeçme alt boyutlarının Türk katılımcılar tarafından anlamlı bulunmadığı görülmüştür. Ölçek maddelerinin toplam puanlarının alınmasıyla bireyin sosyal medyayı sorunlu bir şekilde kullanım ve sosyal medyaya bağımlılık düzeyinin ölçülebilmesi mümkündür. Ayrıca alt boyutların toplam puanları kendi içerisinde ayrı ayrı toplandıklarında bireyin sosyal medyayı sorunlarından kaçı̧ olarak algılama (kaçış), bireyin sosyal medya kullanımını bırakmayı deneyip bırakamama (1srar) ve sosyal medyanın aşırı kullanımından kaynaklanan psikolojik zorlanma hissinin düzeyini (zorlanma) belirleme olanağı bulunmaktadir.

$\mathrm{Bu}$ çalışma kapsamında Van Den Eijnden ve diğerleri (2016) tarafindan geliştirilmiş olan Sosyal Medya Kullanım Bozukluğu Ölçeği'nin Türk katılımcılar tarafından ne şekilde algılandığına ilişkin yürütülen analizler sonucunda orijinal formda yer alan 27 madde ve 9 alt boyuttan 2 alt boyutun aynen korunduğu, 3 farklı alt boyutun birleşerek tek bir faktör altında 
algılandığı 4 alt boyutun ise katılımcılar tarafından anlamlı bulunmadığı gözlenmiştir. Bu durum, ilgili faktörler altında yer alan maddelerin katılımcılara göre bir değer atfediyor olup olmamasıyla alakalıdır. Katılımcılar tarafından anlamlı görülmeyerek faktör yapısından ayrık olarak algılanan maddeleri ele alacak olursak orijinal ölçekte çatışma alt boyutunda yer alan "Geçen yıl boyunca ebeveyn ve kardeşlerle sosyal medya kullanımı sebebiyle ciddi bir çatışma yaşadın mı?" sorusu Türk katılımcılara birçok sebepten yeterince anlamlı gelmemiş olabilir. Bu durumun ölçek maddesinde tercih edilen sözcükler, ölçek maddesinin yapısal özellikleriyle veya kültürel özelliklerle alakalı olması mümkündür. Olası sebeplerden ilki olan sözcük tercihine değinecek olursak her sözcük her kültürde aynı çağrışımları yapmayabilir. Örneğin conflict sözcüğü çatışma sözcüğünün Türkçe karışılığıdır. Fakat cümle içerisinde yarattığı çağrışımlar değişkenlik gösterebilir. Maddede yer alan ebeveyn ve kardeşlerle çatışma ifadesi bazı katılımcılar için fiziki çatışmayı ifade ederken bazıları içinse duygusal veya sözel çatışmayı çağrıştırabilir. Bu durumda konuyla ilgili ailesinde her gün sözel çatışma yaşayan bir birey fiziki bir çatışma yaşamadığı için bu maddeye olumsuz puan vermiș olabilir. Ölçek maddesinin yapısal özellikleri de benzer bir soruna sebep olmuş olabilir. Maddede yer alan "ebeveyn ve kardeşlerle" ifadeleri katılımcıda kafa karışıklığına sebep olmuş olabilir. Bazı katılımcılar ebeveyn ve kardeșlerden birisiyle sözel tartışma yaşıyor olmasına rağmen aynı anda hem ebeveyn hem de kardeşlerle tartışmadığ 1 gerekçesiyle maddeye olumsuz puan vermiş olabilir. Son olarak ölçeğin uygulandığı kitlenin kültürel özellikleri de ölçek maddesinin anlamsız algılanmasında etkili olmuş olabilir. Örneğin ailedeki bireylerin çoğunluğu yoğun olarak telefon kullanıyorsa ve bu yoğun kullanım bir çatışma konusu olmaktan çıkarak kanıksanmış bir düzeye ulaşmışsa bu maddenin anlamsız algılanması doğal olacaktır. Böyle bir kitle üzerinde bu madde anlamlı algılanmayacağından bu maddenin ölçeğin ana gövdesinden bağımsız algılanmış olması mümkün görünmektedir. Bu durum yalnızca çatışma alt boyutunda değil orijinal formda yer almayan tüm maddeler için geçerli olabilir.

$\mathrm{Bu}$ çalışmanın yapılmasındaki temel amaç sosyal medya bağımlılığının ölçülmesinde alternatif bir ölçme aracının araştırmacıların kullanımına sunulmasıydı. Türkiye'de sosyal medya bağımlılığının belirlenmesi için uyarlaması veya geliştirmesi yapılmış az sayıda ölçek bulunmaktadır (Karadağ vd., 2015; Şahin ve Yağc1, 2017). Bununla birlikte Sosyal Medya Kullanım Bozukluğu Ölçeği'nin kısaltılarak uyarlanmış ve tek faktöre düşürülmüş bir başka uyarlaması da gerçekleştirilmiştir (Savcı vd., 2018). Fakat bu çalışmada ise orijinal ölçekteki 27 maddenin tamamı analize dâhil edilmiş ve ölçekteki tüm maddelerin ortaya çıkacak faktör yapısına dâhil olması amaçlanmıştır. Geliştirilmiş olan diğer bir ölçme aracı da Ağyar ve Uzun'a (2018) aittir. Bu ölçekte 3 faktör altında toplanan 26 madde yer almaktadır. Tüm bu çalışmalara bakıldığında açıkça görülmektedir ki alternatif ölçme araçlarının fazlalığı belirgin bir konunun araştırılmasında birçok açıdan avantaj sağlamaktadır. Örneğin Savcı ve diğerlerinin (2018) araştırmasına dayalı olarak 27 maddenin 9'a indirilmesiyle oluşturulan kısa formda daha az özelliğin ölçülmesi amaçlanabileceği gibi, bu çalışmadaki şekliyle daha fazla madde ile ölçüm hassasiyetini artırmaya çalışma düşüncesi hâkim olabilir. Her iki durum da araştırmacının çalışmada izlemeyi planladığı yola göre değişiklik göstermektedir. Öte yandan ölçeğin orijinal cevaplama skalası evet ve hayır şeklinde iki cevaba dayanmaktadır. Savcı ve diğerlerinin (2018) uyarlamalarında sonuçların hassasiyetini artırmayı gerekçe göstererek 5'li Likert'e çevirerek uyarlamayı tercih etmişlerdir. Sonuç olarak eldeki alternatif ölçme araçları birbirinden bağımsız veya farklı uyarlamaların sonucuna dayalı olsa da, bir kavramın ölçümünde yeterli miktarda alternatifin bulunması farklı tipte araştırmalara olanak sağlayabilmektedir. Bununla birlikte ölçeklerde yer alan soru sayılarının fazlalığı bazı konularda sorun yaratabilmektedir. Çok sorulu ölçeklerde katılımcıların sorulara sıkılmadan dürüst cevap verebilme ve araştırmaya katılıma istekli olma düzeyleri azalabilmekte ve bu da elde edilecek sonuçların geçerlik ve güvenirlik düzeylerine doğrudan etki edebilmektedir. Bu açıdan tüm geçerlik ve güvenirlik analizlerinin yapılmış olması ve az soru barındırmış olması açısından, bu çalışmanın araştırmacılara kullanım kolaylığı olan, geçerli ve güvenilir bir ölçme aracı olarak katkı sağlayacağı söylenebilir.

Bu çalışmada bazı sınırlıklar bulunmaktadır. Bu çalışmada, uyarlama çalışmalarında göz önünde bulundurulması gereken tüm temel analizler yapılmış olmasına karşın başka bir araştırma 
ile dış geçerlik düzeyinin sınanmamış olması ve test-tekrar test yöntemiyle güvenirliğin sınanmamış olması bir sınırlık olarak düşünülebilir. İleriki araştırmalarda bu ölçekten elde edilen verilerin kullanılması ile ölçeğin dış geçerliği sınanabilir. Diğer bir sınırlık ise geniş bir çalışma grubunun tercih edilmemiş olması sayılabilir. Bir araştırmada güven aralığı \%95 olarak kabul edildiğinde 385 sayısının en üst düzeyde temsil gücüne sahip olduğu, diğer bir ifadeyle hesaplama formülü dolayısıyla 385 'ten sonra örneklem miktarı-temsil gücü eğrisinin yatay konuma eriştiği bilinmektedir (Cohen vd., 2007). Bu açıdan çalışmadaki 453 olan örneklem miktarı $\% 5$ hata payı için yeterli olsa da seçkisiz bir metotla belirlenmiştir. Gelecek araştırmalarda, sosyal medya kullanım düzeylerinin birbirinden bariz şekilde farklılaşması beklenen popülasyonlar arasından amaçlı bir seçimle belirlenmesi, katılımcı tercihleri açısından daha ayrışmış sonuçların elde edilmesine katkı sağlayabilir.

\section{KAYNAKÇA}

Ağyar, B. B. ve Uzun, B. (2018). Sosyal Medya Bağımlılığı Ölçeği’nin geliştirilmesi: Geçerlik ve güvenirlik çalışmaları. Addicta: The Turkish Journal on Addictions, 5(3), 1-19.

Andreassen, C. S., Billieux, J., Griffiths, M. D., Kuss, D. J., Demetrovics, Z., Mazzoni, E. ve Pallesen, S. (2016). The relationship between addictive use of social media and video games and symptoms of psychiatric disorders: A large-scale cross-sectional study. Psychology of Addictive Behaviors, 30(2), 252-262. http://dx.doi.org/10.1037/adb0000160

Atroszko, P. A., Balcerowsk, J. M., Bereznowski, P., Biernatowsk, A., Pallesen, S. ve Schou Andreassen, C. (2018). Facebook addiction among Polish undergraduate students: Validity of measurement and relationship with personality and well-being. Computers in Human Behavior, 85, 329-338 Contents. https://doi.org/10.1016/j.chb.2018.04.001

Balakrishnan, J. ve Griffiths, M. D. (2017). Social media addiction: What is the role of content in YouTube? Journal of Behavioral Addictions, 6(3), 364-377. https://doi.org/10.1556/ 2006.6.2017.058

Büyüköztürk, Ş. (2002). Sosyal bilimler için veri analizi el kitabı. Pegem Akademi.

Chang, H. C. (2011). A new perspective on Twitter hashtag use: Diffusion of innovation thory. Proceedings of the American Society for Information Science and Technology Banner, 14. https://doi.org/10.1002/meet.14504701295

Cohen, L., Manion, L. ve Morrison, K. (2007). Research methods in education (6th ed.). Rutlege Falmer. https://doi.org/10.1111/j.1467-8527.2007.00388_4.x

Demirci, I. (2019). The adaptation of the bergen social media addiction scale to Turkish and its evaluation of relationship with depression and anxiety symptoms. Anadolu Psikiyatri Dergisi, 21, 15-22. https://doi.org/10.5455/apd.41585

Erdensoy, D. (2018). Bu sosyal medya bağımlılık istatistikleri zamanımızın nereye gittiğini gösteriyor. https://creatorden.com/bu-sosyal-medya-bagimlilik-istatistikleri-zamanimizinnereye-gittigini-gosteriyor/

Griffiths, M. D. (2012). Facebook addiction: Concerns, criticism and recommendations. Psychological Reports, 110(2), 518-520. https://doi.org/10.2466/01.07.18.PR0.110.2.518520

Güneş, N. A., Akbıyık, D. İ., Aypak, C. ve Görpelioğlu, S. (2018). Lise öğrencilerinde sosyal medya bağımlılı̆̆1 ve uyku kalitesi. Türk Aile Hekimliği Dergisi, 22(4), 185-192. https://doi.org/10.15511/tahd.18.00475

Hendricks, D. (2013). Complete history of social media: Then and now. https://smallbiztrends. com/2013/05/the-complete-history-of-social-media-infographic. html. 
Hooper, D., Coughlan, J. ve Mullen, M. R. (2008). Structural equation modelling: guidelines for determining model fit. The Electronic Journal of Business Research Methods, 6(1), 53-60. www.ejbrm.com

Johnson, R. A. ve Wichern, D. W. (2007). Applied multivariate statistical analysis (6th ed.). Prentice Hall.

Jöreskog, K. G. ve Sörbom, D. (1993). LISREL 8: Structural equation modeling with the Simplis Command Language. Lincolnwood: Scientific Software International.

Karadağ, E., Tosuntaş, Ş. B., Erzen, E., Duru, P., Bostan, N., Şahin, B. M., Çulha, İ. ve Babadağ, B. (2015). Determinants of phubbing, which is the sum of many virtual addictions: A structural equation model. Journal of Behavioral Addictions, 4, 1-15. https://doi.org/10.1556/2006.4.2015.005

Kemp, S. (2019). Digital 2019: Global internet use accelarates. https://wearesocial.com/blog/2019/01/digital-2019-global-internet-use-accelerates

Kircaburun, K. ve Griffiths, M. D. (2018). Instagram addiction and the Big Five of personality: The mediating role of self-liking. Journal of Behavioral Addictions, 7(1), 1-13. https://doi.org/10.1556/2006.7.2018.15

Kircaburun, K. (2016). Effects of gender and personality differences on Twitter addiction among Turkish undergraduates. Journal of Education and Practice, 7(24), 33-42.

Kırık, A. M., Arslan, A., Çetinkaya, A. ve Gül, M. (2015). Türkiyedeki gençlerin sosyal medya bağımlılık düzeylerine yönelik nicel bir araştırma. International Journal of Science Culture and Sport, 3(13), 108-108. https://doi.org/10.14486/intjscs444

Kline, P. (1994). An easy guide to factor analysis. Routlege.

Kline, R. B. (2010). Principles and practice of structural equation modeling (3rd ed.). Guilford Press.

Lawshe, C. H. (1975). A quantitative approach to content validity. Personel Psychology, 28, 563575.

Merriam-Webster (2019). Social Media. https://www.merriam-webster.com/dictionary/social media

Moghavvemi, S., Sulaiman, A. B., Jaafar, N. I. B. ve Kasem, N. (2017). Facebook and YouTube addiction: The usage pattern of Malaysian students. International Conference on Research and Innovation in Information Systems, ICRIIS, 1-6. https://doi.org/10.1109/ ICRIIS.2017.8002516

Neuman, L. W. (2011). Social research methods: Qualitative and quantitative approaches (7th ed.). Allyn \& Bacon.

Şahin, C. ve Yağcı, M. (2017). Sosyal Medya Bağımlılı̆̆ı Ölçeği-Yetişkin Formu: Geçerlilik ve güvenirlik çalışması. Ahi Evran Üniversitesi Kırşsehir Eğitim Fakültesi Dergisi, 18(1), 523538.

Savc1, M., Ercengiz, M. ve Aysan, F. (2018). Turkish adaptation of the Social Media Disorder Scale in adolescents. Noropsikiyatri Arsivi, 55(3), 248-255. https://doi.org/10.5152/ npa.2017.19285

Şencan, H. (2005). Sosyal ve davranışsal ölçümlerde güvenilirlik ve geçerlilik. Seçkin.

Singh, N. (2014). A study to analyze relationship between psychological behavioral factors on whatsapp addiction among youth in Jalandhar district in Punjab. European Journal of Business and Management, 6(37), 269-273. http://www.iiste.org/Journals/index.php/ EJBM/article/view/18717 
Tabachnick, B. G. ve Fidell, L. S. (2007). Using multivariate statistics. Pearson.

Terrell, K. (2019). The history of social media: Social networking evolution! https://historycooperative.org/the-history-of-social-media/

Thomas, D. (2018). Motivational beliefs, social media addiction, and interpersonal communication skill among international students in Thailand. International Forum, 21(2), 153-169.

Thompson, B. (2004). Exploratory \& confirmatory factor analysis: Understanding concepts and applications. American Psychological Association.

Van Den Eijnden, R. J. J. M., Lemmens, J. S. ve Valkenburg, P. M. (2016). The Social Media Disorder Scale: Validity and psychometric properties. Computers in Human Behavior, 61, 478-487. https://doi.org/10.1016/j.chb.2016.03.038

\section{EK 1. Sosyal Medya Kullanım Bozukluğu Ölçek Maddeleri}

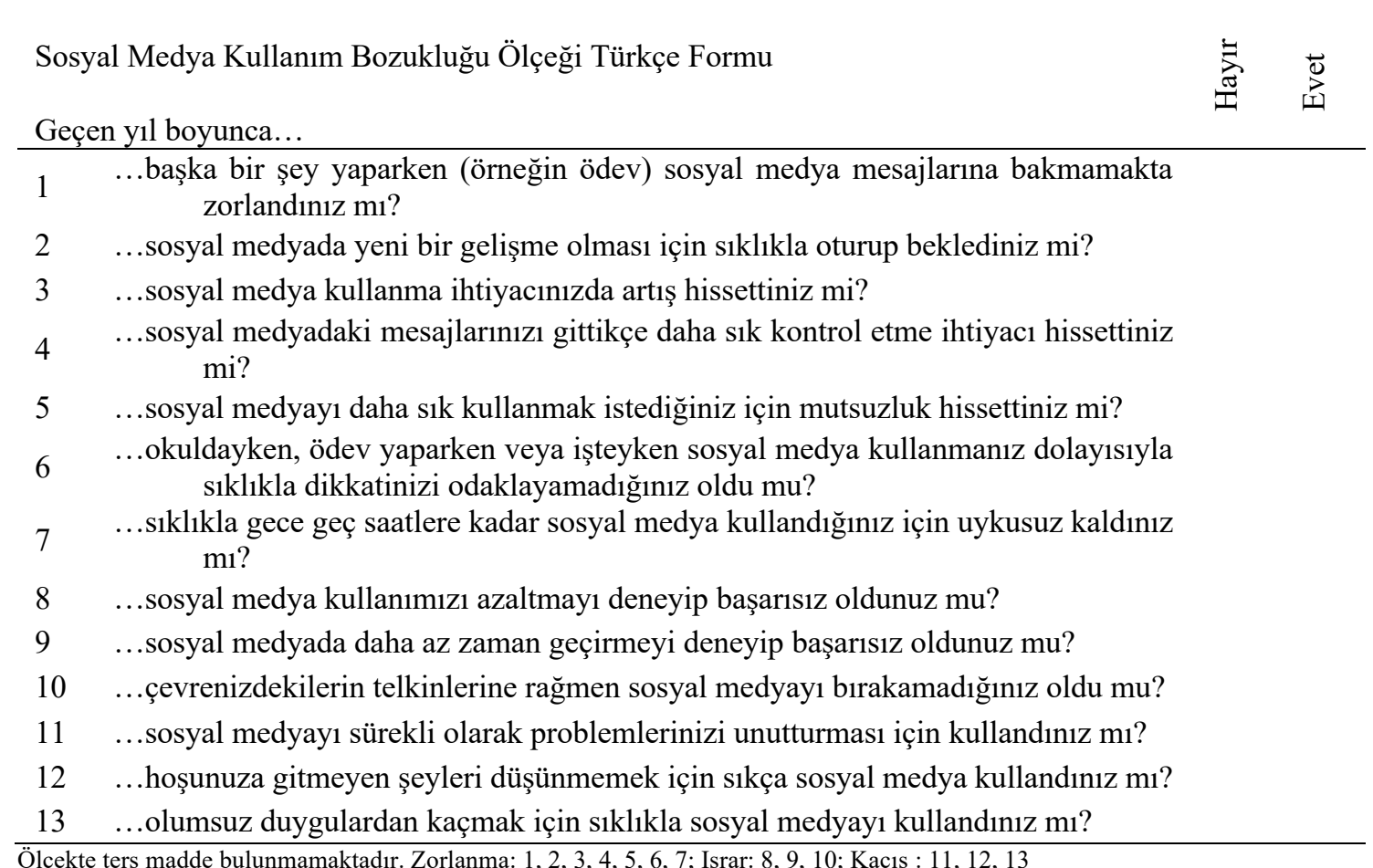

\section{EXTENDED ABSTRACT}

The excessive use of social media started to negatively affect the functioning of daily life and caused an addiction. Social media addiction, which is defined as an individual's inability to stay away from social media for more than an hour (Cited in Thomas, 2018), is one of the important channels of social media, Facebook (Atroszko et al., 2018; Griffiths, 2012), Twitter (Chang, 2011; Kircaburun, 2016), Instagram (Kircaburun \& Griffiths, 2018), Youtube (Balakrishnan \& Griffiths, 2017; Moghavvemi, Sulaiman, Jaafar, \& Kasem, 2017), Whatsapp (Singh, 2014) has become a resource that drives individuals into addiction. This situation made it necessary to develop measurement tools aiming to measure social media addiction. There are some scales in the literature that aim to measure social media addiction (A ğyar \& Uzun, 2018; Andreassen et al., 2016; Karadağ et al., 2015). Social media addiction is measured on each scale with different questions and under different factors. This situation offers researchers the 
opportunity to choose the scale suitable for their purposes. The number of questions of each measurement tool, the duration of application, the number of degrees in the Likert scale may vary. Researchers can choose the scale that is suitable for their purpose and perform measurements in accordance with the content of their studies. Therefore, the existence of a large number of measurement tools that measure the same concept provides an important advantage. For this reason, it is thought that, within the scope of this study, the Social Media Disorder Scale developed by Van Den Eijnden, Lemmens and Valkenburg (2016) will contribute to researchers working in the field of virtual addictions by adapting it to Turkish.

Three (3) separate sample groups were used in the study. Information on sample groups are given below. In order to determine the translation validity of the scale to be adapted, a total of five (5) faculty members, three of whom have completed their master's and doctorate degrees in educational sciences abroad, and two of them in the department of English Language and Literature participated in the study. The experts translated the scale items into Turkish independently from each other and then scored the reverse translation operations. In the Turkish language and meaning validity study, two experts from the Turkish Language Teaching Department participated in the study and scored the comprehensibility level of the translated items in Turkish. The sample group determined for the pilot application consists of 453 students, 231 girls (51\%) and 222 boys (49\%), who continue their university education (Avg: 20.78, Sd: 2.20). Participants' ages range from 18 to 39 . For the scale to be adapted, Translation Validity Conformity Form (i) Turkish Language and Meaning Validity Conformity Form (ii) was applied to the experts.

Participants were given (i) Personal Information Form developed by researchers, (ii) Social Media Addiction (Karadağ et al., 2015), (iii) Bergen Social Media Addiction Scale (Demirci, 2019), and (iv) Social Media Disorder Scale (Van Den Eijnden et al., 2016) which will be adapted with this study.

Within the scope of validity studies, first of all, translation, language and meaning validity studies were conducted. The opinions of five experts were used for translation validity and two experts for language and meaning validity. For translation validity, Lawshe content validity coefficient (Lawshe, 1975) as a result of the scores given by experts to translation validity forms, and Cohen Kappa agreement index scores for language and meaning validity were used. As a result of the experts scoring the scale items, it was seen that the translation validity coefficient for the items had a coefficient of 1.00 , which corresponds to $100 \%$. Cohen Kappa agreement index was calculated in order to determine whether the Turkish equivalents of the translated scale items were clearly understood. It can be said that the values obtained as a result of both analyzes are at acceptable levels (Lawshe, 1975; Şencan, 2005).

After the scale, which was ready for implementation, was tested on the participants, the findings regarding the validity and reliability level of the scale were determined. As a result of the exploratory factor analysis, it was observed that 13 items were gathered under 3 dimensions. When the items in the three sub-dimensions determined were examined, it was determined that the two sub-dimensions were escape and continuity sub-dimensions, which were also included in the original factor structure, while the other sub-dimension consisted of items indicating dysfunction caused in daily life. It was determined that there were 7 items in the three-dimension strain sub-dimension and three items in the escape and continuity sub-dimension. Although the results in the exploratory factor analysis indicate that there is a statistically integrity, the researchers should control whether there is a semantic integrity in the structure or not, in order to determine whether this relationship is conceptually verified or not. This type of analysis is called nomological analysis in the literature (Şencan, 2005). Therefore, it was examined whether there is a semantic integrity or not, since there is conceptual consistency of the stress factor, which is not included in the original form and that emerged within the scope of this study. As a result of the analysis, it was determined that the items belonging to the stress factor emphasize the problems caused by social media in daily life, in other words, they are similar in terms of 
negatively affecting the functioning of daily life. The structural validity of the items was confirmed as a result of the CFA performed to determine the validity of the obtained factors. The reliability coefficient obtained for the escape and continuity sub-dimensions were . 71 , the strain sub-dimension determined within the adaptation study was .72., and for the whole scale was .76. The findings obtained as a result show that a valid and reliable measurement tool has been developed in studies to be conducted in the field of virtual addictions. 